\title{
EVALUATION OF THE INFLUENCE OF THE SUPPLY PRESSURE ON FUNCTIONAL PARAMETERS OF THE IMPULSE LOW-PRESSURE GAS-PHASE INJECTOR
}

\author{
Dariusz SZPICA*, Andrzej BORAWSKI*, Grzegorz MIECZKOWSKI", Michał KUSZNIER**, \\ Mohamed M. AWAD ${ }^{*+*}$, Adel M. SADIK ${ }^{*+1+}$, Mohammed SALLAH
}

\author{
${ }^{*}$ Faculty of Mechanical Engineering, Bialystok University of Technology, 45C Wiejska Str., 15-351 Bialystok, Poland \\ ${ }^{*}$ Doctoral School, Bialystok University of Technology, 45A Wiejska Str., 15-351 Bialystok, Poland \\ ${ }^{* * *}$ Mechanical Power Engineering Department, Faculty of Engineering, Mansoura University, Mansoura 35516, Egypt \\ ${ }^{* * * *}$ Physics Department, Faculty of Science, Mansoura University, Mansoura 35516, Egypt \\ ${ }^{* * * * *}$ Physics Department, Faculty of Science, Mansoura University, Mansoura 35516, Egypt, \\ Higher Institute for Engineering and Technology, New Damietta, Egypt
}

d.szpica@pb.edu.pl, a.borawski@pb.edu.pl, g.mieczkowski@pb.edu.pl, michal.kusznier@gmail.com, m_m_awad@mans.edu.eg, sadikama@mans.edu.eg, msallahd@mans.edu.eg

received 23 November 2020, revised 15 January 2021, accepted 19 January 2021

\begin{abstract}
The article presents research results referring to the influence of supply pressure on the functional parameters of the impulse low-pressure gas-phase injector. The study was done on the original stand for flow test of gas-phase injectors. In the indirect evaluation, with the initial parameters and the length of the forced impulse, the current line, acceleration and pressure sensor courses were used. Apart from the volumetric flow rate, the analysed parameters were the time periods of the injector opening and closing process. Those time segments were composed of response time and opening/closing time, the sum of which gives time of full opening. Functional relationships describing the volumetric flow rate, time of full opening and closing are presented, which are helpful not only in comparative tests of different injectors, but also in modelling the operation of gas injector or algorithms of gas supply control system. The reference to the volumetric flow rate allowed to indicate possible causes of variability of this parameter depending on the supply pressure.
\end{abstract}

Key words: Mechanical engineering, combustion engines, fuel supply, alternative fuel injector, research

\section{INTRODUCTION}

In recent years, we have seen legislative efforts to reduce exhaust emissions from engines used in transport (WLTP, 2019). This is generally known as greenhouse gases (GHGs) (Clairotte et al., 2020). Although some of the regulations are European, manufacturers around the world are adapting their engines to the requirements of the next Euro emission limits, considering distribution issues (Kim et al., 2020). In 2018, $\mathrm{CO}_{2}$ emissions during a European car certification test could reach $120.5 \mathrm{~g} / \mathrm{km}$. Since 2020 , this has been reduced to $95 \mathrm{~g} / \mathrm{km}$. In a longer-term perspective, further reductions by $15 \%$ in 2025 and $37.5 \%$ in 2030 are planned (García et al., 2020). Such actions will most probably exclude the possibility of using combustion engines as the only source of vehicle propulsion. However, they may still be used in hybrid systems with different connection configurations (Raslavičius et al., 2015, 2017). A separate issue proposed for inclusion in the future Euro VII standard is the unification of exhaust emissions for cars, vans, and trucks. There are still matters of emissions for machines and non-road vehicles (Waluś et al., 2018; Warguła et al., 2018).

In Europe, the most popular alternative fuel used in cars and vans is liquefied petroleum gas (LPG) (Raslavičius et al., 2014). Alternative fuels are listed in the European Union Directive (2014/94/EU) (Council of the European Union, 2014). Interest in using LPG/CNG in forklift and working machinery engines is also observed (Warguła et al., 2020, 2020a).
Taking into consideration the emission regulations, more precise algorithms are required to monitor the performance of the internal combustion engine, and in particular towards the gas fuel supply (Dziewiatkowski et al., 2020). More precise executive modules are also required (Szpica, 2016). Additionally, it is necessary to know the working characteristics of the components in relation to variable input parameters.

The impulse low-pressure gas-phase injectors, which are installed in alternative combustion engine supply systems, are characterized by their diverse design. Out of many parameters, which can describe the operation of the gas injector, the volumetric flow rate (Czarnigowski, 2012) and the time periods associated with the movement of the actuator (Duk and Czarnigowski, 2012; Szpica, 2018) are considered as basic.

For the functional evaluation of the gas injectors, computational methods used for modelling the operation of engines and their components may be used:

- 0-D modelling (Baldi et al., 2015; Feng et al., 2019; Ngayihi Abbe et al., 2015; Polášek et al., 2002);

- 1-D modelling (Cerri et al., 2006; Da Silva Trindade and Dos Santos, 2016; Sawant and Bari, 2017; Pauras Sawant et al., 2018);

- 3-D modelling (Broatch et al., 2019; Buhl et al., 2017; Kosmadakis et al., 2012; Mohammadi et al., 2012).

Calculation methods are becoming essential when prototyping new construction solutions. Analytical models are used here (Brumercik et al., 2020; Szpica and Kusznier, 2020). For strength 
and thermal evaluation, the finite element method (FEM) is widely used (Bensetti et al., 2006; Borawski et al., 2020, 2021), while in the flow part, computational fluid dynamics (CFD) (Czarnigowski et al., 2007, 2009; Marčič et al., 2015; Szpica, 2015). A very difficult computational problem is the phenomenon of circuit magnetism with an injector drive coil (Passarini and Nakajima, 2003; Passarini and Pinotti, 2003; Taghizadeh et al., 2009). In gas injectors, as in other fuel injectors, there are high hopes for piezoelectric propulsion (Mieczkowski, 2019; Mieczkowski et al., 2020; Pogulyaev et al., 2015; Satkoski et al., 2009).

Mathematical modelling allows for the approximation of real processes, but in effect, experimental verification is required. For testing gas injectors, experimental methods used for functional analysis of injectors for different fuels can be applied:

- high speed cameras (Aleiferis et al., 2010; Jang et al., 2000; Panão and Moreira, 2005);

- optical laser (Kakuhou et al., 1999; Leach et al., 2007; Robart et al., 2001);

- light fluorescence absorption (Aleiferis and Van Romunde, 2013; Leach et al., 2007);

- current in the power line (Duk and Czarnigowski, 2012; Szpica, 2018);

- heat flow sensors (Serras-Pereira et al., 2013);

- acceleration sensors (Czarnigowski, 2012; Szpica, 2018);

- pressure sensors (Duk and Czarnigowski, 2012; Szpica, 2018);

- lift sensors (Ambrozik and Kurczyński, 2008; Szpica, 2018);

- optical sensors (Walaszyk and Busz, 2013);

- gravimetric method (Szpica and Czaban, 2014);

- 'fuel tank refill' method (Szpica and Czaban, 2014).

The methods presented above differ in the level of complexity, the required equipment, as well as the way they interfere with the executive parts. The use of direct methods gives the most precise picture of the processes, but this often involves interfering with the working system, which must be repaired at a later stage. As shown in (Szpica, 2018) indirect methods, which exclude interference with the working elements of the gas injector, also allow for a correct assessment of functional parameters.

On the one hand, the emission regulations and, on the other hand, the expansion of the control algorithms within the engine require knowledge not only of the static characteristics, but also of their changes when adjusting the input parameters. The main feature of the injector, which is the volumetric flow rate, has been improved by time intervals for opening and closing the injector, filling the research gap in this area. The aim of the study was to develop functional dependencies describing the variability of the analysed parameters that may be helpful in the analysis of engine transitions as well as in creating mathematical models.

\section{THE RESEARCH OBJECT}

The object of the research was STAG AC W02 - four-section injection rail LPG/CNG (Fig. 1a). W02 is the impulse low-pressure gas-phase injector. In the lack of power supply, plunger 1 (Fig. 1b) is pressed against the socket by spring 3 and gas flow is not possible. When an electrical impulse arises in circuit 2, the electromagnetic force raises plunger 1 and the gas flow is realized according to the red arrows (Fig. 1). When the electric impulse disappears, spring 3 moves plunger 1 downwards, making the flow impossible. a)

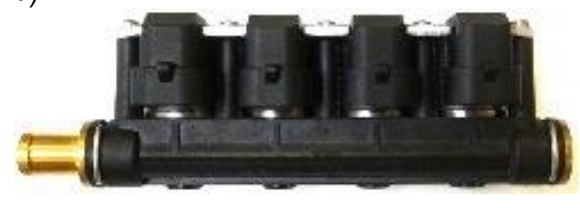

b)

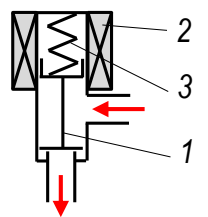

Fig. 1. STAG AC W02 - four-section injection rail LPG/CNG: a - picture; b-scheme: 1 - plunger, 2 - electromagnetic circuit, 3 - spring, red arrows point at the flow direction

Basic technical data of the STAG AC W02 - four-section injection rail LPG/CNG have been presented in Tab. 1.

Tab. 1. Basic technical data of the Valtek Rail Type 30 gas injector Data taken from (AC, 2020)

\begin{tabular}{|l|c|}
\hline \multicolumn{1}{|c|}{ Parameter } & Value \\
\hline max flow rate at 1.2 bar & $120 \mathrm{NL} / \mathrm{min}$ \\
\hline coil resistance & $1.9 \Omega$ \\
\hline nozzle size & $(\min 1.5 / \mathrm{max} 2.8) \mathrm{mm}$ \\
\hline opening time/closing time & $(2 / 1) \mathrm{ms}$ \\
\hline operating temperature & $(-20 \div 120)^{\circ} \mathrm{C}$ \\
\hline max working pressure & $400 \mathrm{kPa}$ \\
\hline
\end{tabular}

\section{THE RESEARCH METHODOLOGY}

The tests were carried out on the original gas injector flow test stand. For safety reasons, the tests were conducted using air instead of LPG/CNG (Fig. 2). In the evaluation of functional parameters, indirect methods were used without interfering with the injector's working system.

Compressed air from air supply 1 flows through the air preparation 2 system to the buffer tank 3 . The buffer tank is designed to accumulate sufficient air to prevent temporary pressure drops. The air continues to flow through the tested injector 4 . The impulse action of the injector is controlled by a pulse generator 5 .

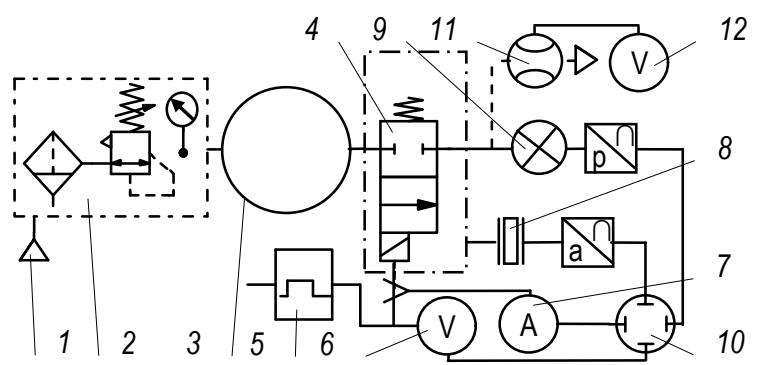

Fig. 2. The scheme of the measurement stand: 1 - air supply

2 - air preparation system, 3 - buffer tank, 4 - tested injector,

5 - pulse generator (based STAG ECU), 6 - voltage connector;

7 - current lines, 8 - accelerometer, 9- pressure gauge,

10 - oscilloscope, 11 - mass flow meter, 12 - multimeter

In the measurement section that assesses the power supply, there is a voltage connector 6 and current line 7 . The return positions of the injector plunger are accompanied by vibrations, which are read out by the accelerometer 8 . The air stream coming out of the injector under test goes to the pressure sensor 9 , which estimates the operating cycle in terms of flow-through. The design and operation of pressure sensor 9 is described in Szpica (2018). 
Dariusz Szpica, Andrzej Borawski, Grzegorz Mieczkowski, Michał Kusznier, Mohamed M. Awad, Adel M. Sadik, Mohammed Sallah Evaluation of the Influence of the Supply Pressure on Functional Parameters of the Impulse Low-Pressure Gas-Phase Injector

Signals are stored in oscilloscope 10. In addition, it is possible to measure the average injector output through the mass flow meter 11 and multimeter Brymen 907 12. Basic technical data of the measurement equipment have been presented in Tab. 2.

By using an oscilloscope, it was possible to register 4 different channels. Assuming that the voltage supply to the injector is forced, the corps acceleration, current line, and pressure are additionally recorded. The registered values were saved to *.csv file. The results were processed using software created in Guide
Matlab-Simulink. A Butteworth low pass filter (Yang et al., 2005) was used to filter the waveforms. As a result, it was possible to read the times describing the injector reaction when opening and closing (Fig. 3). Based on the 'breakthrough' of the current line, only the time to full opening $\left(t_{f}\right)$ could be read. The acceleration course and the pressure course made it possible to read both response of opening or closing time $\left(t_{o r}, t_{c r}\right)$ and opening time $\left(t_{0}\right)$ or closing time $\left(t_{c}\right)$. By adding up response time and opening/closing time as a result, we get time to full opening/closing.

Tab. 2. Parameters of the measuring equipment

\begin{tabular}{|l|l|c|c|c|c|}
\hline Parameter & \multicolumn{1}{|c|}{ Measurement device } & Response time & Range & Output signal & Accuracy \\
\hline current & HAMEG HZ050 & $<1 \mu \mathrm{s}$ & $\pm 30 \mathrm{~A}$ & $100 \mathrm{mV} / \mathrm{A}$ & $1 \%$ \\
\hline acceleration & KELAG KAS903-02A & $<1 \mathrm{~ms}$ & $\pm 12 \mathrm{~g}$ & $(0.5-4.5) \mathrm{V}$ & $0.005 \mathrm{~g}$ \\
\hline pressure & MPXH6400A & $<1 \mathrm{~ms}$ & $(20-400) \mathrm{kPa}$ & $(0-5) \mathrm{V}$ & $0.25 \%$ \\
\hline mass flow & BRONKHORST F-113AC-M50-ABD-00-V & $<0.5 \mathrm{~s}$ & $(0-300) \mathrm{N} / \mathrm{min}$ & $(0-5) \mathrm{V}$ & $0.5 \%$ \\
\hline voltage & RIGOL RP1500A & \multicolumn{2}{|l|}{ bandwidth $\sim 150 \mathrm{MHz}$; damping factor - 10:1 } \\
\hline record & RIGOL MSO4014 & \multicolumn{2}{|l|}{ bandwidth $-100 \mathrm{MHz}$; real-time sample rate - up to $4 \mathrm{GSa} / \mathrm{s}$} \\
\hline
\end{tabular}

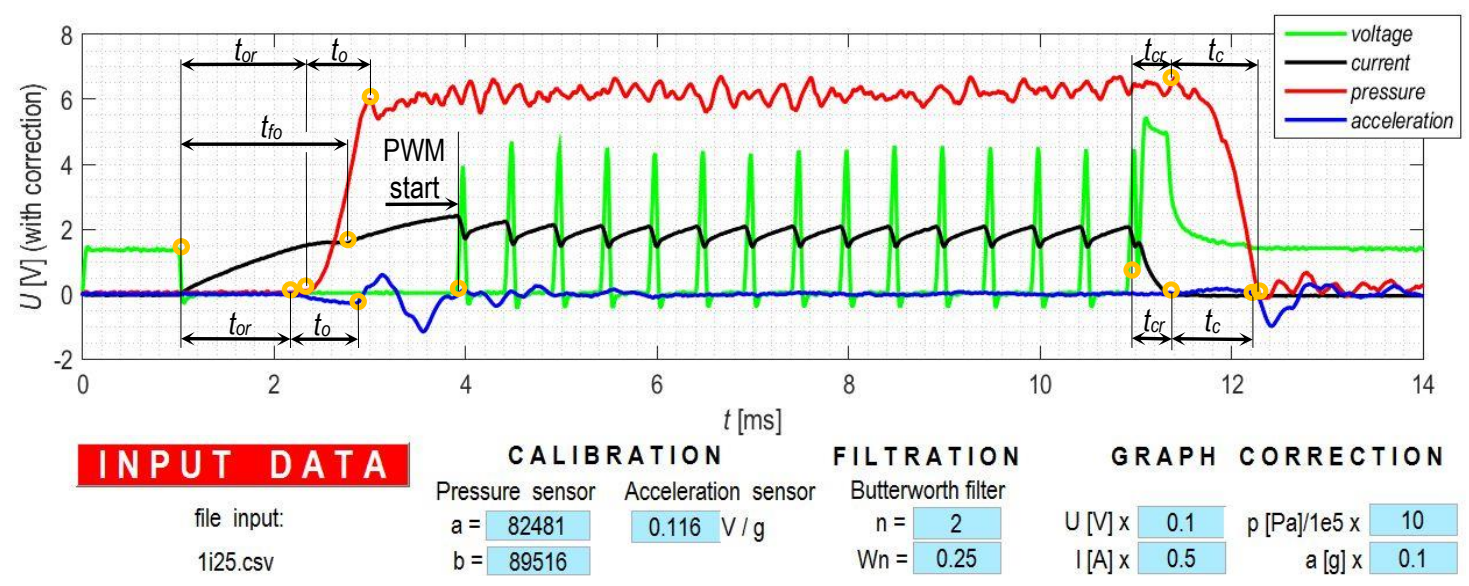

Fig. 3. Example courses recorded during the measurement (injection impulse $10 \mathrm{~ms}$, PWM after $3 \mathrm{~ms}$ ): $t$ - time; index: or - of opening response, 0 - of opening, fo - of full opening, $c r$ - of closing response, $c$ - of closing

\section{RESULTS OF THE MEASUREMENT}

In the initial part of the study, the volumetric flow rate was determined using the flow meter. The supply pressure regulated in the scope (0.5-2.5) e5 $\mathrm{Pa}$. The pulse generator has been set with constant parameters: frequency of impulses: $1000 \mathrm{~min}^{-1}$; injection time: $10 \mathrm{~ms}$; signal modulation $90 \%$ PWM at $3 \mathrm{~ms}$; voltage: $14 \mathrm{~V}$; outlet nozzle diameter: $3.2 \mathrm{~mm}$.

The variability of volumetric flow rate relative to supply pressure was presented in the Fig. 4. The relation $Q=f(p)$ was approximated with the polynomial of 3rd degree:

$Q=-1.1612 p^{2}+13.9160 p+1.2933\left(R^{2}=99.9 \%\right)(1)$

It was found that a 9-fold increase in supply pressure results in an approximate 6-fold increase in volumetric flow rate, the ratio is not proportional. In the study (Czarnigowski, 2012), the results of the volumetric flow rate tests of constructively similar injectors were presented. Despite the differences in values, the variability of the tested parameters correlates with the one presented in this study.

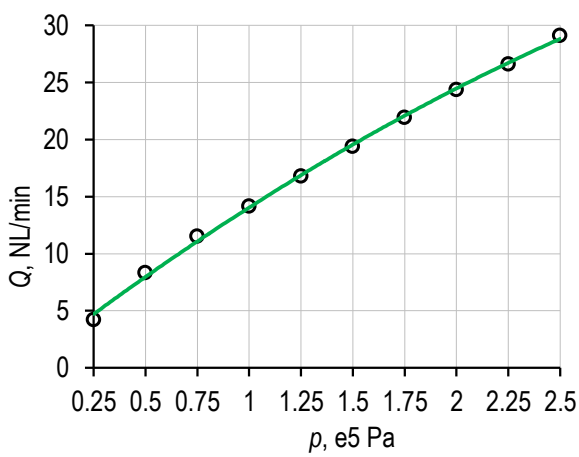

Fig. 4. The relation of the volumetric flow rate and the supply pressure for the tested injector

In order to maintain the necessary relationship towards comparison, the variability of time characterizing the injector operation was also approximated with the polynomial of 3rd degree. Functional dependencies have been determined for time to full opening and full closing. Full opening time based on the current course was described (Fig. 5a)

$$
t_{\text {fo }}=-0.0358 p^{2}+0.3066 p+1.4355\left(R^{2}=99.7 \%\right)(2)
$$


and the acceleration sensor course

$t_{f o}=-0.0485 p^{2}+0.3263 p+1.5380\left(R^{2}=99.5 \%\right)(3)$

also the pressure sensor course

$t_{f o}=-0.0200 p^{2}+0.2308 p+1.7478\left(R^{2}=99.1 \%\right)(4)$

In case of evaluation of the injector closing process, it is im- possible to evaluate it on the basis of the current line. Therefore, the ratios defining time to full closing are described based on the acceleration sensor course (Fig. $5 \mathrm{~d}$ )

$t_{f c}=0.0109 p^{2}-0.1102 p+2.3383\left(R^{2}=95.0 \%\right)$

and the pressure sensor course

$t_{f c}=0.0333 p^{2}-0.0531 p+2.3498\left(R^{2}=82.9 \%\right)$ a)

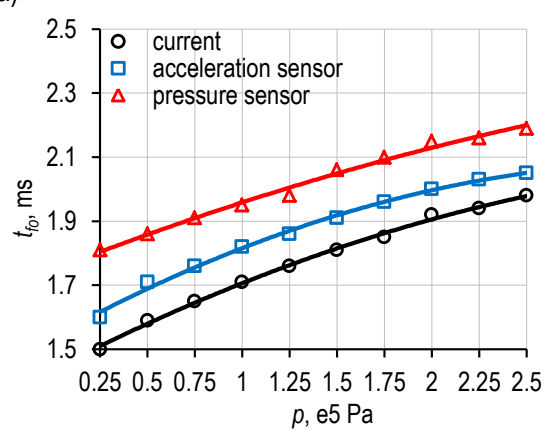

d)

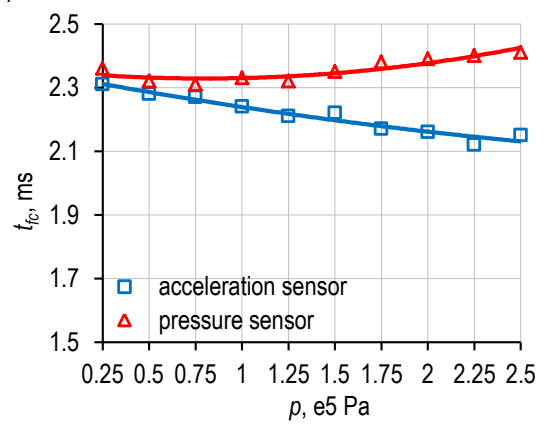

b)

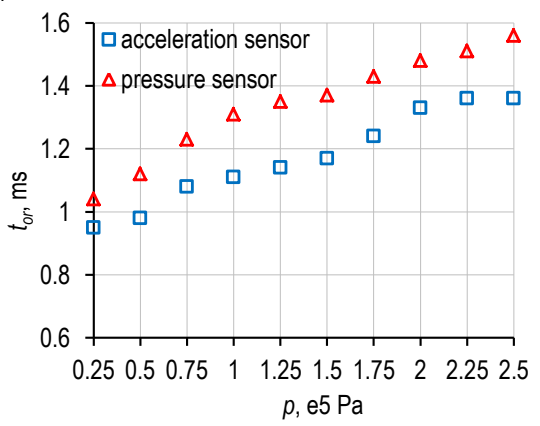

e)

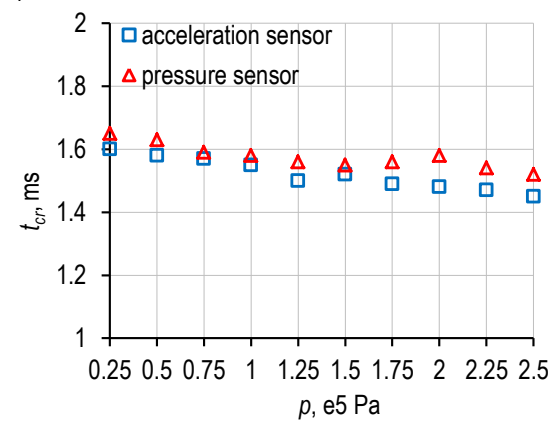

c)

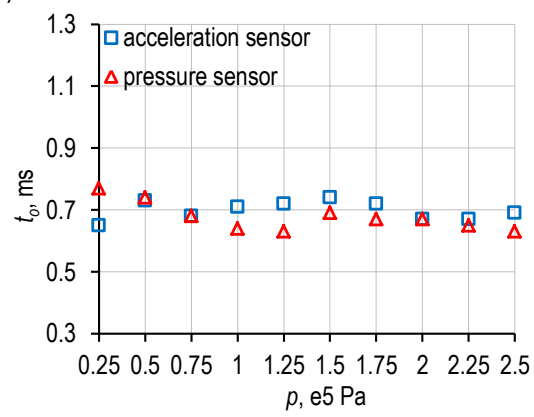

f)

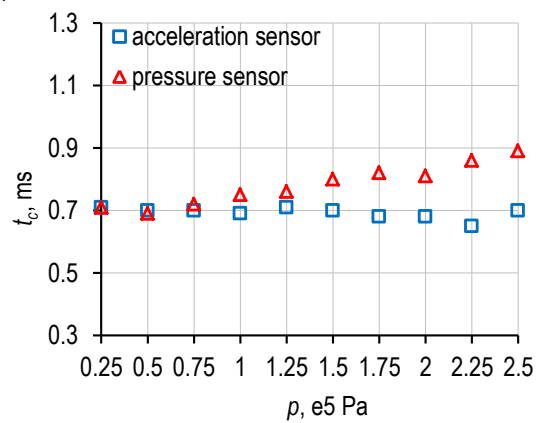

Fig. 5. The results of the research: $a$ - time to full opening, $b$ - opening response time, $c$ - opening time, $d$ - time to full closing, $e$-response closing time, $f$ - closing time

In the case of time to full opening variability, it was found that a 9-fold increase in supply pressure gives time to full opening increments in the range $20-32 \%$, current line $-32 \%$, acceleration sensor $-28 \%$ and pressure sensor $-21 \%$ accordingly. Analysing Fig. $5 b$ and $c$, the dominant influence of opening response time is observed. It results from the necessity to overcome the force from the differential pressure above and below the piston by the electromagnetic force of the drive. The opening process itself is characterized by similar time values, due to the disappearance of the pressure difference under and over the piston.

The closing process of the injector and the associated characteristic times are more difficult to estimate using indirect methods. While the acceleration sensor shows a $7.5 \%$ decrease in time to full closing, the pressure sensor shows a $2 \%$ increase. In this case, the accelerator sensor should be considered as representative, because in the pressure sensor and its course of pressure in the process of closing the injector, there is still a phase of air stream expansion between the injector and the sensor, as described in Szpica (2018). On the basis Fig. 5e and f for the acceleration sensor, it is possible to state the major influence of response time on time to full closing.

The presented results of research on the influence of supply pressure on functional parameters of the impulse low-pressure gas-phase injector correlate with the research and conclusions from the experimental studies presented in (Czarnigowski, 2010, 2014). It was found there that the supply pressure has an impact on the opening response time because, as already mentioned, the electromagnetic force has to overcome the greater pressure difference under and over the piston. However, there was no confirmation with reference to the characteristic times of the opening and closing process. An analysis of opening and closing times of the injector can be helpful in developing an algorithm to control the operation of the supply system at variable gas pressure regarding the change in injection angle.

The results obtained in the course of the research are also the base for the verification of mathematical models describing the operation of the gas injector, for example Szpica and Kusznier (2020).

\section{CONCLUSIONS}

The studies presented in the article and their analysis were intended to evaluate the influence of supply pressure on the functional parameters of the impulse low-pressure gas-phase injector. The parameters evaluated were volumetric flow rate and time intervals describing the process of opening and closing the injector. The conclusions are as follows,

- A 9-fold increase of supply pressure gives a 6-fold increase in the volumetric flow rate. The relation was approximated with the polynomial of 3rd degree; 
- Changes in supply pressure in the scope covered by the research plan result in time to full opening increases of a range $20-32 \%$.

- The opening response time has a more significant impact on the time to full opening than opening time.

- The acceleration sensor shows a $7.5 \%$ decrease in time to full closing, with a significantly higher impact on response time than closing time.

- The pressure sensor gives a $2 \%$ increase in time to full closing, but its course during closing process is not fully representative, which takes into account the expansion phase of the stream between injector and sensor.

The study results presented in the article fill the research gap regarding the evaluation of the influence of supply pressure on the examined time periods. They are also helpful in creating mathematical models describing the operation of the gas injector or planning algorithms for controlling the gas supply system. In the next stage, it is planned to verify the research presented in the study by the direct method using the displacement sensor.

\section{REFERENCES}

1. AC (2020), STAG Autogas Section. Retrieved May 10, 2020, from https://www.ac.com.pl/en.

2. Aleiferis P. G., Serras-Pereira J., Augoye A., Davies T. J., Cracknell R. F., Richardson D. (2010), Effect of fuel temperature on innozzle cavitation and spray formation of liquid hydrocarbons and alcohols from a real-size optical injector for direct-injection sparkignition engines, International Journal of Heat and Mass Transfer, 53(21-22): 4588-4606.

3. Aleiferis P. G., Van Romunde Z. R. (2013), An analysis of spray development with iso-octane, n-pentane, gasoline, ethanol and $n$ butanol from a multi-hole injector under hot fuel conditions, Fuel, 105: 143-168.

4. Ambrozik A., Kurczyński D. (2008), Analysis of fast-changing quantities in the AD3.152 UR engine running of mineral fuel, plant fuel and their blends, Motrol, 10: 11-22.

5. Baldi F., Theotokatos G., Andersson K. (2015), Development of a combined mean value-zero dimensional model and application for a large marine four-stroke Diesel engine simulation, Applied Energy 154: 402-415.

6. Bensetti M., Le Bihan Y., Marchand C. (2006), Development of an hybrid 3D FEM for the modeling of micro-coil sensors and actuators, Sensors and Actuators, A: Physical, 129(1-2): 207-211.

7. Borawski A., Szpica D., Mieczkowski G., Awad M. M., Shalby R. M., Sallah M. (2021), Simulation study of the vehicle braking process with temperature dependent coefficient of friction between brake pad and disc, Heat Transfer Research, 52(2): 1-11.

8. Borawski A., Szpica D., Mieczkowski G., Borawska E., Awad M. M., Shalby R. M., Sallah M. (2020), Theoretical analysis of the motorcycle front brake heating process during high initial speed emergency braking, Journal of Applied and Computational Mechanics, 6(SI): 1431-1437.

9. Broatch A., Olmeda P., Margot X., Escalona J. (2019), New approach to study the heat transfer in internal combustion engines by 3D modelling, International Journal of Thermal Sciences, 138: 405415.

10. Brumercik F., Lukac M., Caban J., Krzysiak Z., Glowacz A. (2020), Comparison of selected parameters of a planetary gearbox with involute and convex-concave teeth flank profiles, Applied Sciences (Switzerland), 10(4): 1417.

11. Buhl S., Gleiss F., Köhler M., Hartmann F., Messig D., Brücker C., Hasse C. (2017), A combined numerical and experimental study of the 3D tumble structure and piston boundary layer development during the Intake stroke of a gasoline engine, Flow, Turbulence and
Combustion, 98: 579-600.

12. Cerri T., Onorati A., Mattarelli E. (2006), 1D engine simulation of a small HSDI diesel engine applying a predictive combustion model, Journal of Engineering for Gas Turbines, 130(1): 012802.

13. Clairotte M., Suarez-Bertoa R., Zardini A. A., Giechaskiel B., Pavlovic J., Valverde V., Ciuffo B., Astorga C. (2020), Exhaust emission factors of greenhouse gases (GHGs) from European road vehicles, Environmental Sciences Europe, 32(1): 125.

14. Council of the European Union (2014), Council Directive 2014/94/EU of 22 October 2014 on the deployment of alternative fuels infrastructure. In Official Journal of the European Union.

15. Czarnigowski J. (2010), The impact of supply pressure on gas injector expenditure characteristics, Silniki Spalinowe, 49(2): 18-26.

16. Czarnigowski J. (2012), Theoretical and empirical study of modelling a pulse gas injector. Wydawnictwo Politechniki Lubelskiej, Lublin.

17. Czarnigowski J. (2014), Experiments on the effect of pressure and voltage supply on pulse injector opening time, SAE Technical Papers, 2014-01-2560.

18. Czarnigowski J., Jakliński P., Wendeker M., Pietrykowski K., Grabowski $Ł$. (2009), The analyses of the phenomena inside a CNG flap-valve injector during gas flow, Combustion Engines, 136(1): 10 18.

19. Czarnigowski J., Wendeker M., Jakliński P., Rola M., Grabowski Ł., Pietrykowski K. (2007), CFD model of fuel rail for LPG systems, SAE Technical Papers, 2007-01-2053.

20. Da Silva Trindade W. R., Dos Santos R. G. (2016), Combustion modeling applied to engines using a 1D simulation code, SAE Technical Papers, 2016-36-0347.

21. Duk M., Czarnigowski J. (2012), The method for indirect identification gas injector opening delay time, Przeglad Elektrotechniczny, 88(10 B): 59-63.

22. Dziewiatkowski M., Szpica D., Borawski A. (2020), Evaluation of impact of combustion engine controller adaptation process on level of exhaust gas emissions in gasoline and compressed natural gas supply process, Engineering for Rural Development, 19: 541-548.

23. Feng Y., Wang H., Gao R., Zhu Y. (2019), A zero-dimensional mixing controlled combustion model for real time performance simulation of marine two-stroke diesel engines, Energies, 12(10): 2000.

24. García A., Monsalve-Serrano J., Villalta D., Guzmán-Mendoza M. (2020), Methanol and OMEx as fuel candidates to fulfill the potential EURO VII emissions regulation under dual-mode dual-fuel combustion, Fuel, 287: 119548.

25. Jang C., Kim S., Choi S. (2000), An experimental and analytical study of the spray characteristics of an intermittent air-assisted fuel injector, Atomization and Sprays, 10(2): 199-217.

26. Kakuhou A., Urushihara T., Itoh T., Takagi Y. (1999), Characteristics of mixture formation in a direct injection SI engine with optimized in-cylinder swirl air motion, Journal of Engines, 108: 550-558.

27. Kim H. J., Lee S. H., Kwon S. I., Park S., Lee J., Keel J. H., Lee J. T., Park S. (2020), Investigation of the emission characteristics of light-duty diesel vehicles in korea based on EURO-VI standards according to type of after-treatment system, Energies, 13(18): 4936.

28. Kosmadakis G. M., Rakopoulos C. D., Demuynck J., De Paepe M., Verhelst S. (2012), CFD modeling and experimental study of combustion and nitric oxide emissions in hydrogen-fueled sparkignition engine operating in a very wide range of EGR rates, International Journal of Hydrogen Energy, 37(14): 10917-10934.

29. Leach B., Zhao H., Li Y., Ma T. (2007), Two-phase fuel distribution measurements in a gasoline direct injection engine with an airassisted injector using advanced optical diagnostics, Proceedings of the Institution of Mechanical Engineers, Part D: Journal of Automobile Engineering, 221(6): 663-673.

30. Marčič S., Marčič M., Praunseis Z. (2015), Mathematical model for the injector of a common rail fuel-injection system, Engineering, 7 : 307-321.

31. Mieczkowski G. (2019), Static electromechanical characteristics of piezoelectric converters with various thickness and length of piezoelectric layers, Acta Mechanica et Automatica, 13(1): 30-36. 
32. Mieczkowski G., Borawski A., Szpica D. (2020), Static electromechanical characteristic of a three-layer circular piezoelectric transducer, Sensors (Switzerland), 20(1), 222.

33. Mohammadi A., Jazayeri A., Ziabasharhagh M. (2012), Numerical simulation of direct injection engine with using porous medium, Proceedings of the Spring Technical Conference of the ASME Internal Combustion Engine Division, ICES2012-81150, pp. 785-795.

34. Ngayihi Abbe C. V., Nzengwa R., Danwe R., Ayissi Z. M., Obonou M. (2015), A study on the 0D phenomenological model for diesel engine simulation: Application to combustion of Neem methyl esther biodiesel, Energy Conversion and Management, 89: 568-576.

35. Panão M. R. O., Moreira A. L. N. (2005), Flow characteristics of spray impingement in PFI injection systems, Experiments in Fluids, 39(2): 364-374.

36. Passarini L. C., Nakajima P. R. (2003), Development of a highspeed solenoid valve: an investigation of the importance of the armature mass on the dynamic response, Journal of the Brazilian Society of Mechanical Sciences and Engineering, 25(4): 329-335.

37. Passarini L. C., Pinotti M. (2003), A new model for fast-acting electromagnetic fuel injector analysis and design, Journal of the Brazilian Society of Mechanical Sciences and Engineering, 25(1): 95106

38. Pogulyaev Y. D., Baitimerov R. M., Rozhdestvenskii Y. V. (2015), Detailed dynamic modeling of common rail piezo injector, Procedia Engineering, 129: 93-98.

39. Polášek M., Macek J., Takáts M., Vítek O. (2002), Application of advanced simulation methods and their combination with experiments to modeling of hydrogen fueled engine emission potentials, SAE Technical Papers, 2002-01-0373.

40. Raslavičius L., Azzopardi B., Keršys A., Starevičius M., Bazaras Ž., Makaras R. (2015), Electric vehicles challenges and opportunities: Lithuanian review, Renewable and Sustainable Energy Reviews, 42: 786-800.

41. Raslavičius L., Keršys A., Makaras R. (2017), Management of hybrid powertrain dynamics and energy consumption for 2WD, 4WD, and HMMWV vehicles, Renewable and Sustainable Energy Reviews, 68: 380-396

42. Raslavičius L., Keršys A., Mockus S., Keršiene N., Starevičius M. (2014), Liquefied petroleum gas (LPG) as a medium-term option in the transition to sustainable fuels and transport, Renewable and Sustainable Energy Reviews, 32: 513-525.

43. Robart D., Breuer S., Reckers W., Kneer R. (2001), Assessment of pulsed gasoline fuel sprays by means of qualitative and quantitative laser-based diagnostic methods, Particle and Particle Systems Characterization, 18(4): 179-189.

44. Satkoski C. A., Shaver G. M., More R., Meckl P., Memering D. (2009), Dynamic modeling of a piezoelectric actuated fuel injector IFAC Proceedings Volumes, 42(26): 235-240.

45. Sawant P., Bari S. (2017), Combined effects of variable intake manifold length, variable valve timing and duration on the performance of an internal combustion engine, ASME International Mechanical Engineering Congress and Exposition, Proceedings (IMECE), IMECE2017-70470, V006T08A052.

46. Sawant Pauras, Warstler M., Bari S. (2018), Exhaust tuning of an internal combustion engine by the combined effects of variable exhaust pipe diameter and an exhaust valve timing system, Energies,
11(6): 1545.

47. Serras-Pereira J., Aleiferis P. G., Walmsley H. L., Davies T. J., Cracknell R. F. (2013), Heat flux characteristics of spray wall impingement with ethanol, butanol, iso-octane, gasoline and E10 fuels, International Journal of Heat and Fluid Flow, 44: 662-683.

48. Szpica D. (2015), Simplified numerical simulation as the base for throttle flow characteristics designation, Mechanika, 21(2): 129-133.

49. Szpica D. (2016), The influence of selected adjustment parameters on the operation of LPG vapor phase pulse injectors, Journal of Natural Gas Science and Engineering, 34: 1127-1136.

50. Szpica D. (2018), Validation of indirect methods used in the operational assessment of LPG vapor phase pulse injectors, Measurement: Journal of the International Measurement Confederation, 118: 253-261.

51. Szpica D., Czaban J. (2014), Operational assessment of selected gasoline and LPG vapour injector dosage regularity, Mechanika, 20(5): 480-488.

52. Szpica D., Kusznier M. (2020), Modelling of the low pressure gas injector operation, Acta Mechanica et Automatica, 14(1(51)): 29-35.

53. Taghizadeh M., Ghaffari A., Najafi F. (2009), Modeling and identification of a solenoid valve for PWM control applications, Comptes Rendus - Mecanique, 337(3): 131-140.

54. Walaszyk A., Busz W. (2013), Application of optical method for the analysis delay between control injector coil and beginning of the fuel injection, Combustion Engines, 154(3): 1038-1041.

55. Waluś K. J., Warguła Ł., Krawiec P., Adamiec J. M. (2018), Lega regulations of restrictions of air pollution made by non-road mobile machinery - the case study for Europe: a review, Environmental Science and Pollution Research, 25(4): 3243-3259.

56. Warguła Ł., Kukla M., Lijewski P., Dobrzyński M., Markiewicz F. (2020), Influence of the use of Liquefied Petroleum Gas (LPG) systems in woodchippers powered by small engines on exhaust emissions and operating costs, Energies, 13: 5773.

57. Warguła Ł., Kukla M., Lijewski P., Dobrzyński M., Markiewicz F. (2020a), Impact of Compressed Natural Gas (CNG) fuel systems in small engine wood chippers on exhaust emissions and fuel consumption, Energies, 13(24): 6709

58. Warguła L., Waluś K. J., Krawiec, P. (2018), Small engines spark ignited (SI) for non-road mobile machinery- Review. Transport Means - Proceedings of the International Conference, 2018-Octob, 585-591.

59. WLTP (2019). WLTP lab test. Retrieved November 1, 2019, from http://wltpfacts.eu/.

60. Yang W. Y., Cao W., Chung T.-S., Morris J. (2005), Applied Numerical Methods Using MATLAB®. In Applied Numerical Methods Using MATLAB尺

This research was performed as a part of international cooperation under contract no. 147-UWBWM-2019 sign on 8th April 2019 between Bialystok University of Technology and Mansoura University, and it was financed through subsidy of the Ministry of Science and Higher Education of Poland for the discipline of mechanical engineering at the Faculty of Mechanical Engineering Bialystok University of Technology WZ/WMIIM/4/2020 